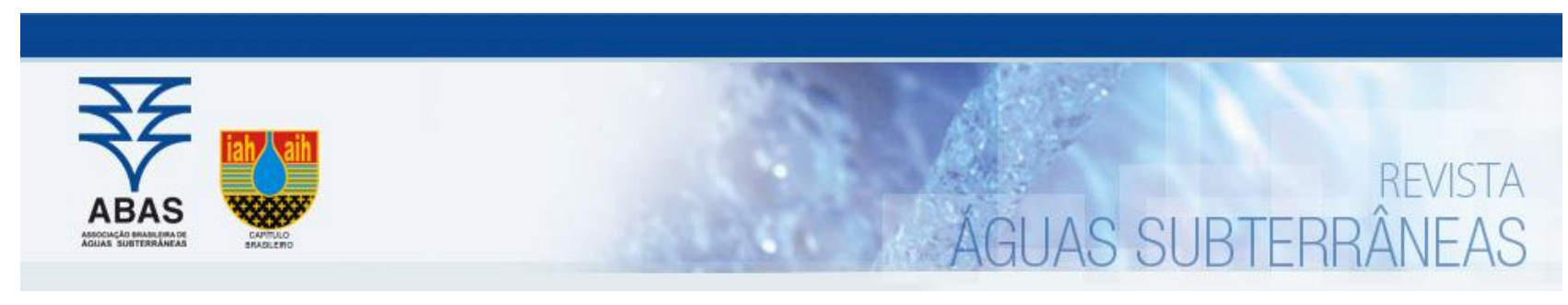

Artigos

\title{
Hydrogeological and numerical criteria for groundwater withdrawal permission in the Marizal-São Sebastião Aquifer, State of Bahia, Brazil
}

\author{
Critérios Hidrogeológicos para Outorga de Água Subterrânea no Sistema \\ Aquífero Marizal-São Sebastião, Bahia, Brasil
}

\author{
Rosialine Marques Roedel${ }^{1}$; lara Brandao de Oliveira ${ }^{1}$ \\ 1 Federal University Bahia (UFBA), Salvador, BA \\ $\bowtie$ rosialine1@yahoo.com.br, oliveira@ufba.br
}

\author{
keywords: \\ Groundwater; \\ Modelling; \\ Water permit; \\ Sustainability.
}

\begin{abstract}
Groundwater is part of the water supply for industrial use in the Camaçari Industrial Complex (CIC) (Bahia, 2016). Managers from the $\mathrm{CIC}$ developed a computational model to evaluate exploitation of groundwater, the Regional Numerical Flow Model (RNFM), which has the function of calculating groundwater volumes for withdrawal in order to choose the best location for the pumping wells and to establish the aquifer hydrological equilibrium during the regime of groundwater withdrawal. In addition to the current management this work proposes hydrogeological criteria for granting groundwater withdrawal permission from the Marizal-São Sebastião aquifer system in the CIC region. To introduce the hydrogeological criteria, this work developed a new water zoning for the aquifer; calculated the water reserves and potentials for each zone; and classified the water zones in terms of the degree of exploitation favorability. To confirm the adequacy of the proposed criteria, this work reevaluated a previous permission process in the region (11 pumping wells), for which the NRFM established the well locations and the groundwater volumes to exregion (11 pumping wells), for which the NRFM established the well locations and the groundwater volumes to ex-
plore. This work verified that using only the NRFM, which is the current management tool for granting groundwater withdrawal licenses in the CIC region, is not conservative enough for sustainable groundwater withdrawal in each water zone. Using the combination of hydrogeological and numerical methodologies for the pumping wells would result in a better choice for well locations in water zones with larger groundwater potential and favorability, thus promoting a sustainable groundwater exploitation.
\end{abstract}

Resumo

\section{Palavras-chave:}

Água Subterrânea;

Modelagem;

Outorga;

Sustentabilidade.

Revisão por pares.

Recebido em: 10/12/2020

Aprovado em: 24/05/2021.
Uma parcela significativa do abastecimento de água para uso industrial do Complexo Industrial de Camaçari (CIC) é suprida pela água subterrânea. Um Modelo de Fluxo Numérico Regional (MFNR) foi desenvolvido para a região com a finalidade de avaliar os volumes de água subterrânea adequados para captação e a escolha de locais mais adequados para instalação dos poços de bombeamento, de modo a estabelecer equilíbrio hidrológico do aquífero durante a captação de água subterrânea. Adicionalmente à gestão atual, este trabalho propõe critérios técnicos hidrogeológicos para outorga de água subterrânea do sistema aquífero Marizal-São Sebastião na região do CIC. Para introduzir os critérios hidrogeológicos adicionais, este trabalho desenvolveu um novo zoneamento hídrico para o aquífero; calculou as reservas e potenciais de água para cada zona; e classificou as zonas hídricas em termos do grau de favorabilidade à exploração. Para confirmar a adequação dos critérios propostos, este trabalho reavaliou um processo de outorga concedido na região (11 poços de bombeamento), para o qual o MFNR estabeleceu as localizações dos poços e os volumes de água subterrânea a serem explotadas. Este trabalho verificou que o uso apenas do MFNR, que é a ferramenta de gestão atual para concessão de licenças de captação de água subterrânea na região $\mathrm{CIC}$, não é conservador o suficiente para a captação sustentável de água subterrânea em cada zona de água. O uso da combinação de metodologias hidrogeológicas e numéricas para os poços de bombeamento resultaria em uma melhor escolha de localizações de poços em zonas hídricas com maior potencial e favorabilidade hídrica subterrânea, promovendo assim a explotação sustentável das águas subterrâneas.

DOI: http:/dx.doi.org/10.14295/ras.v35i2.29990

\section{INTRODUÇÃO}

Aquifers play an important role as water supply because groundwater is the main source of fresh water in the world (SHIKLOMANOV; RODDA, 2003). Unauthorized groundwater use, overexploitation, depletion and contamination are real problems nowadays undermining ecosystems and human supplies (TERRELL et al., 2002; DE STEFANO; LOPEZ-GUN, 2012). This scenario complicates human access to safe water supplies, a challenge identified by the international community since the seventies (CASTRO, 2007; WHO 2014).

According to Gleick (1993) the notion of water crisis emerged in the early nineties and since then the scientific literature and international organizations have work together designing new management policies related to the access and use of water, the water availability and degradation (LALL et al., 2008, Villar 2015). The degradation of water resources reduces the 
chance of reaching the goal of universal access to safe water and escalates the investment in sanitation. For instance, most of the Brazilian hydrographic regions present critical areas regarding qualitative and/or quantitative aspects according to the Regulation ANA n 62/2013, consequently, the deterioration of surface waters tend to increase the extraction of groundwater (ANA, 2015).

Regulations to assess the groundwater resource, at an early stage, before its depletion, may be crude but helpful to establish a groundwater allocation system to avoid over-exploitation. An aquifer can return to hydrologic equilibrium only by reducing extraction or re-allocating production wells, whenever it is impossible to provide alternative supplies. In general, the conventional models for groundwater governance are unsuccessful in restricting groundwater use, failing badly to stop the accelerating rate of depletion. In many cases, the users consider the groundwater overexploitation as a reward, outweighing the current and future costs of depletion. Consequently, the governance processes are failing to observe the status of the groundwater system, to develop effective plans, and implement necessary measures for better governance. Increasing the rates of groundwater withdrawal, based on the concept of private ownership of groundwater will lead to storage declines and groundwater management failure. The best strategy for groundwater management is maximizing economic utility of aquifers, while sustaining the environmental conditions, which depends on how to value the future uses (MOENCH et al., 2005).

In Brazil, there is a significant variation in the technical criteria for groundwater granting among the states. Some states primarily consider the hydraulic aspects of the well and the hydrogeological studies of aquifers. Others consider only the principles of legislation and economic and social factors. The Brazilian Law no. 9.433 (BRAZIL, 1997) regulates the management of water resources at the federal level and induces the creation of decrees at the state level. However, in the state of Bahia, despite the existence of the State Water Resources Plan and the Law No. 11.612/2009 there are no instructions for the groundwater granting procedures, besides basic rules for granting or waiving the grant. Thus, the technical criteria for groundwater withdrawal permission do not have general tools for regional assessment of water availability and sustainable groundwater allocations. Lack of technical criteria is one of the main problems faced by groundwater managers attempting to control groundwater use worldwide, as illustrated with several agricultural and urban case studies (DE STEFANO; LOPEZGUNN, 2012; MONTGINOUL; RINAUDO, 2011).

In the Camaçari Industrial Complex (CIC), Camaçari, Bahia, Brazil, groundwater plays an important role as the water supply for industrial use, which led managers to develop a computational model to evaluate exploitation of groundwater, the Regional Numerical Flow Model (RNFM). This important tool is uti- lized to evaluate proper volumes for withdrawal, to choose the best location for the pumping wells and to establish the aquifer hydrological equilibrium during the regime of groundwater withdrawal. However, with the growth of the Industrial Complex and the increasing water demand, the model (RNFM) by itself, turned out to be insufficient for granting groundwater withdrawal licenses. For instance, the water volumes granted and the hydrological equilibrium isolines distribution had indications that the RNFM was lacking precision to simulate the withdrawal scenarios, probably due to the lack of hydrogeological information necessary for an adequate modeling. Moreover, how much impact on surface water bodies or how much groundwater drawdown would be acceptable? From this perspective, there is a need for other tools capable of considering additional acceptance criteria. The RNFM, even a precise one, does not have embedded all acceptance criteria to support the granting of requested water permit.

Therefore, this paper proposes complementary hydrogeological criteria in addition to using the RNFM model, for granting groundwater withdrawal licenses in the Camaçari Industrial Complex. The test of the new methodology used a previous license for 11 pumping wells established in the region.

\section{CURRENT GROUNDWATER MANEGEMENT PRACTICE IN THE STUDY AREA AND ITS LIMITATION}

The study area is located in the northeastern portion of the state of Bahia, Brazil (Figure 1). The Camaçari Industrial Complex (CIC) (magenta lines) is located between the cities of Camaçari and Dias D'Avila (in dark gray), within the RNFM domain (red lines).

Lima (1999) describes the aquifer system of the study area with two components, the phreatic aquifer, constituted by three geologic formations (Barreiras, Marizal, and São Sebastião upper portion), and the semi-confined aquifer (São Sebastião Formation). The geological formations are sandwiched of semi consolidated stratigraphic sandy to clay units.

The Marizal-São Sebastião aquifer system in the study area is part of the Reconcavo Sedimentary Basin. The CIC region is located in an extensive plain with watersheds displaying strong hydraulic interconnection with groundwater reserves of the Reconcavo Sedimentary Basin and nearby estuarine systems. In the study area, the main aquifer of the Reconcavo Basin are sandstones from the São Sebastião Formation, a $1.000 \mathrm{~m}$ thick aquifer, exploited to supply the industrial activities from the $\mathrm{CIC}$, and neighboring cities and communities. Figure 2 shows a cross-sectional hydrogeological section between the cities of Camaçari and Dias D'Avila with layers of sand and clays alternately deposited on the sandstones or on the shales dipping in the NW direction. 
Figure 1 - Study Area Location

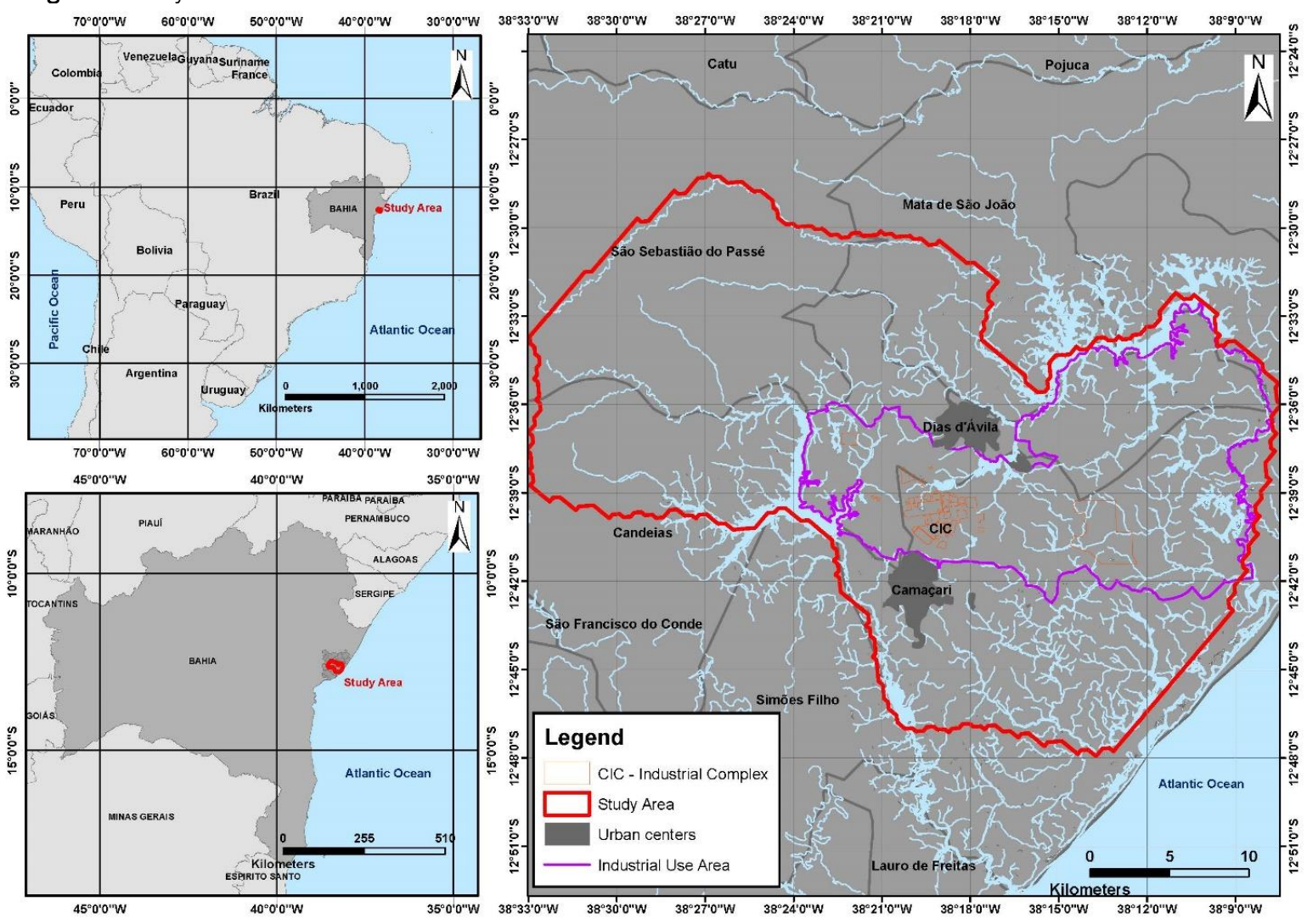

Figure 2 - Hydrogeological Section Transverse to the Reconcavo Aquifer System in the Camaçari Area - Dias D'Avila

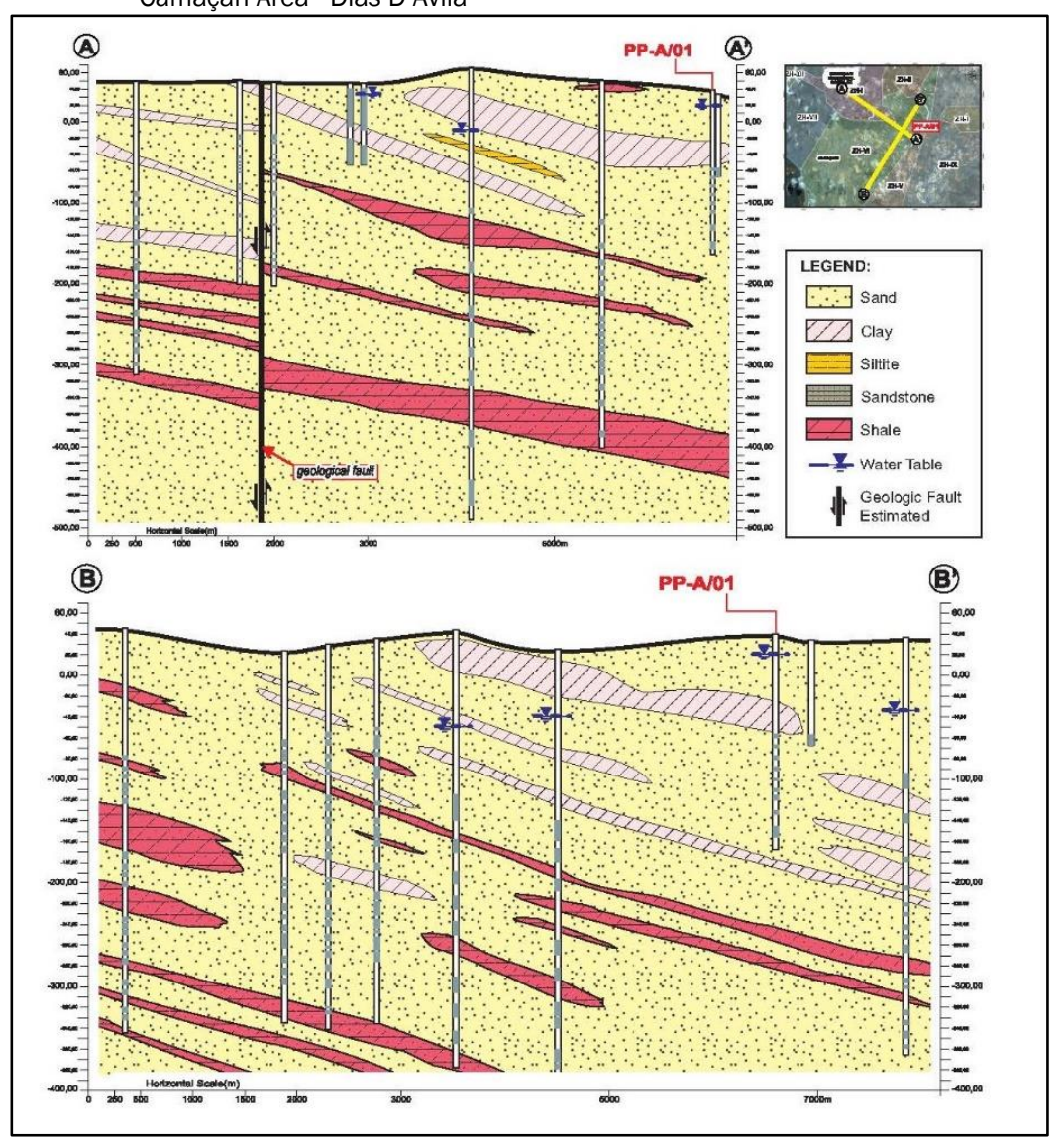

Source: Roedel (2017). 
The hydrogeological characterization of the region indicates the presence of semi-confined, deeper aquifer layers (above $200 \mathrm{~m}$ depth) with shale layers in the upper portion. The geological faults indicate structural discontinuities of these clay layers, with hydraulic connection between aquifers in various points of the region.

Groundwater quality of the Marizal-São Sebastião aquifer system is excellent. Water samples are constantly collected from wells and results show geochemical characteristics appropriate to potable use. In fact, there are many mineral water companies in this region producing bottled water due to these physical-chemical characteristics.

According to Bredehoeft (2002) the correct way to assess the dynamic process of the exploitation of an aquifer system is through evaluating its pumping capture zones and areas affected by drawdown. Moreover, the author states that groundwa- ter modelling is the main instrument utilized to evaluate dynamics of groundwater systems, and is also a crucial way to achieve sustainable groundwater development.

The groundwater managers from $\mathrm{CIC}$ use the RNFM model to predict the capture zones and well drawdowns related to exploitable groundwater volume. Before drilling new pumping wells, different scenarios are simulated to evaluate the impact of pumping and predict depletion on the aquifer system. For instance, in a semi-confined aquifer it should be observed whether the pumping is causing significant drawdowns which can affect groundwater supply for other surrounding users. The first version of the RNFM model using Visual Modflow was employed to build the first proposed zoning for groundwater exploitation in the area. Henceforth, the water zones were updated every 3 years, the last version of Water Zoning is shown in Figure 3.

Figure 3 - Water Zoning 2013

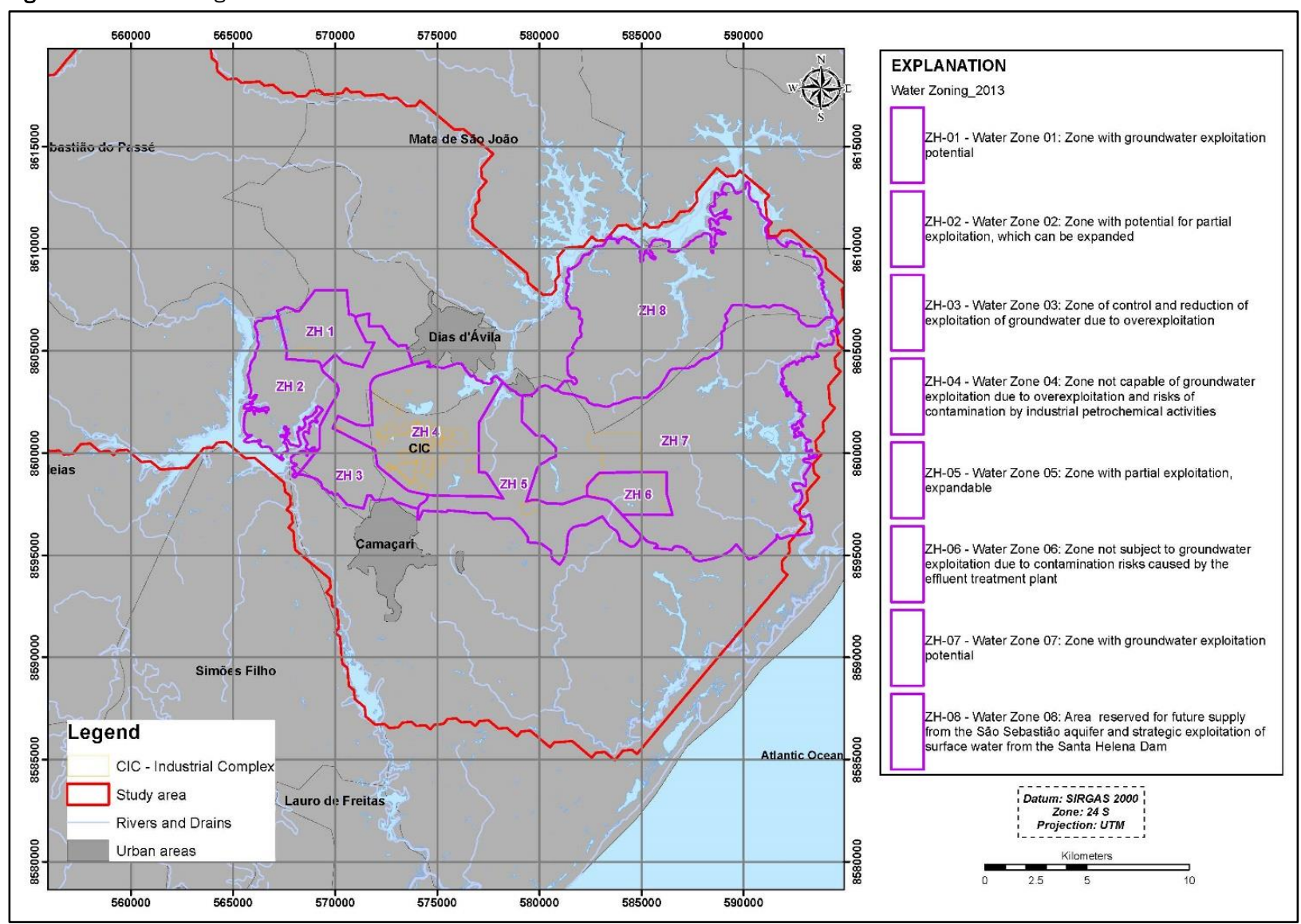

Source: Adapted from Bahia (2013)

The groundwater management team verified that the hydrogeological complexity of the Marizal-São Sebastião aquifer system in the $\mathrm{CIC}$ region, shown in Figure 2, had incomplete representation in the RNFM management model. Although the RNFM considers the presence of hydraulic connection between layers, in some local situation this may not be the case. As a result, RNFM simulations can calculate well draw- downs not verified in field measurements.

To illustrate the limitation of using only the RNFM for groundwater withdrawal license, this work evaluated the implementation of 11 production wells (yellow dots), in the year 2004 , located in the northern region of the CIC area (Figure 4). 
Figure 4 - Location of the proposed production wells

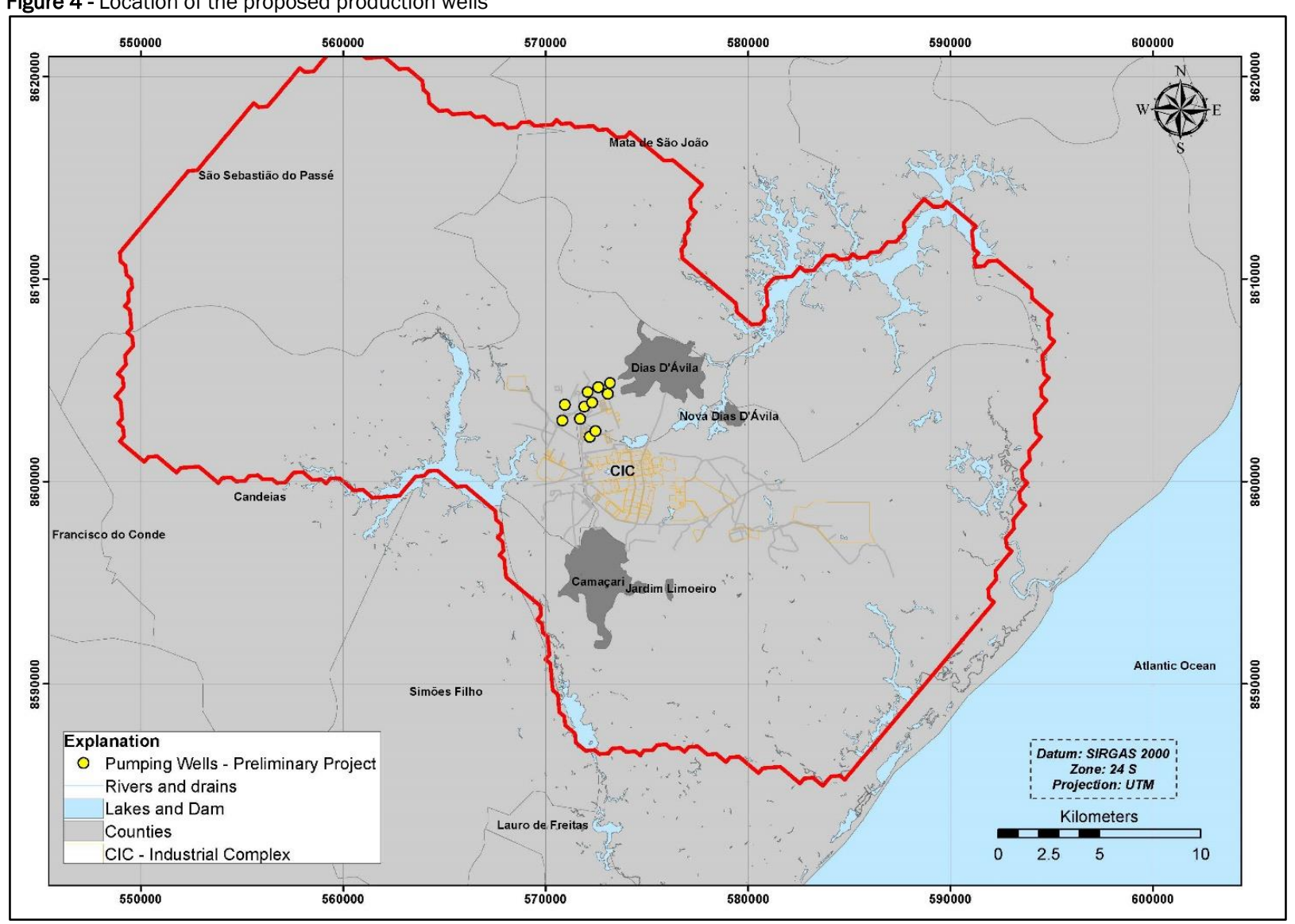

Using the RNFM, the simulation of capture zones and drawdowns for the 1111 pumping wells had the ability to indicate interference between them (Figure 5), as well as indicating drawdown zones with an area of influence as large as 9 km (Figure 6).

Therefore, the recommendation was to increase well spacing to avoid well interference, while maintaining the averaged well depth of $450 \mathrm{~m}$ and the required total flow rate of 50,400 $\mathrm{m}^{3} /$ day. Groundwater managers from CIC did not have additional arguments to suggest a reduction in the water withdrawal volumes. Simulation of capture zones and drawdown caused by pumping rate did not indicate significant depletion of groundwater locally. The subsequent installation of the 11 pumping wells between 2004 and 2005, did not comply with the recommendation of larger spacing between wells and, in 2009, the state of Bahia water resources authority gave the withdrawal permission for operation of the pumping wells.
Consequently, in 2009, when the 11wells started pumping, the overall drawdown of approximately 100 meters occurred near the wells, which was much higher than the expected 40 meters for each well. Additionally, interference between wells occurred during simultaneous well operation, requiring a reduction of the operational flow.

Besides uncertainties and limitations regarding the RNFM, it is necessary to better comprehend the role of natural recharge as a criterion to achieve sustainable pumping rates in the aquifer system. Although, Bredehoeft (2002) states that capture is independent of the natural recharge, Zhou Y. (2009) asserts the importance of natural recharge on the water balance equation to calculate sustainable pumping rate. In other words, despite capture being defined through dynamic balance between induced recharge and decreased discharge, the groundwater storage will continuously use total recharge (natural recharge plus induced recharge) to balance the pumping rate. 
Figure 5 - Simulation using RNFM: capture zones for 30 years of travel time

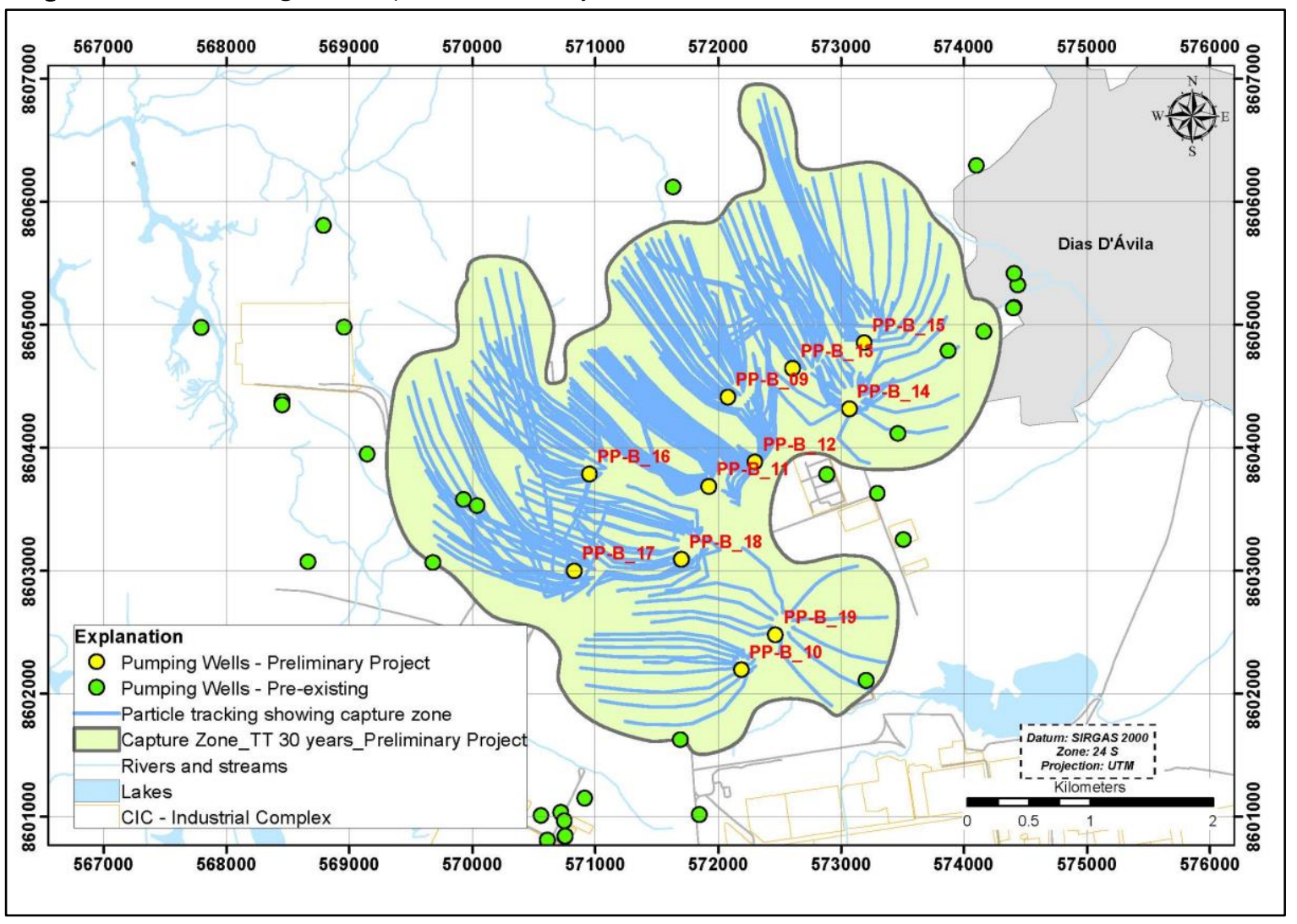

Figure 6 - Simulation using RNFM: maximum drawdown at the first layer

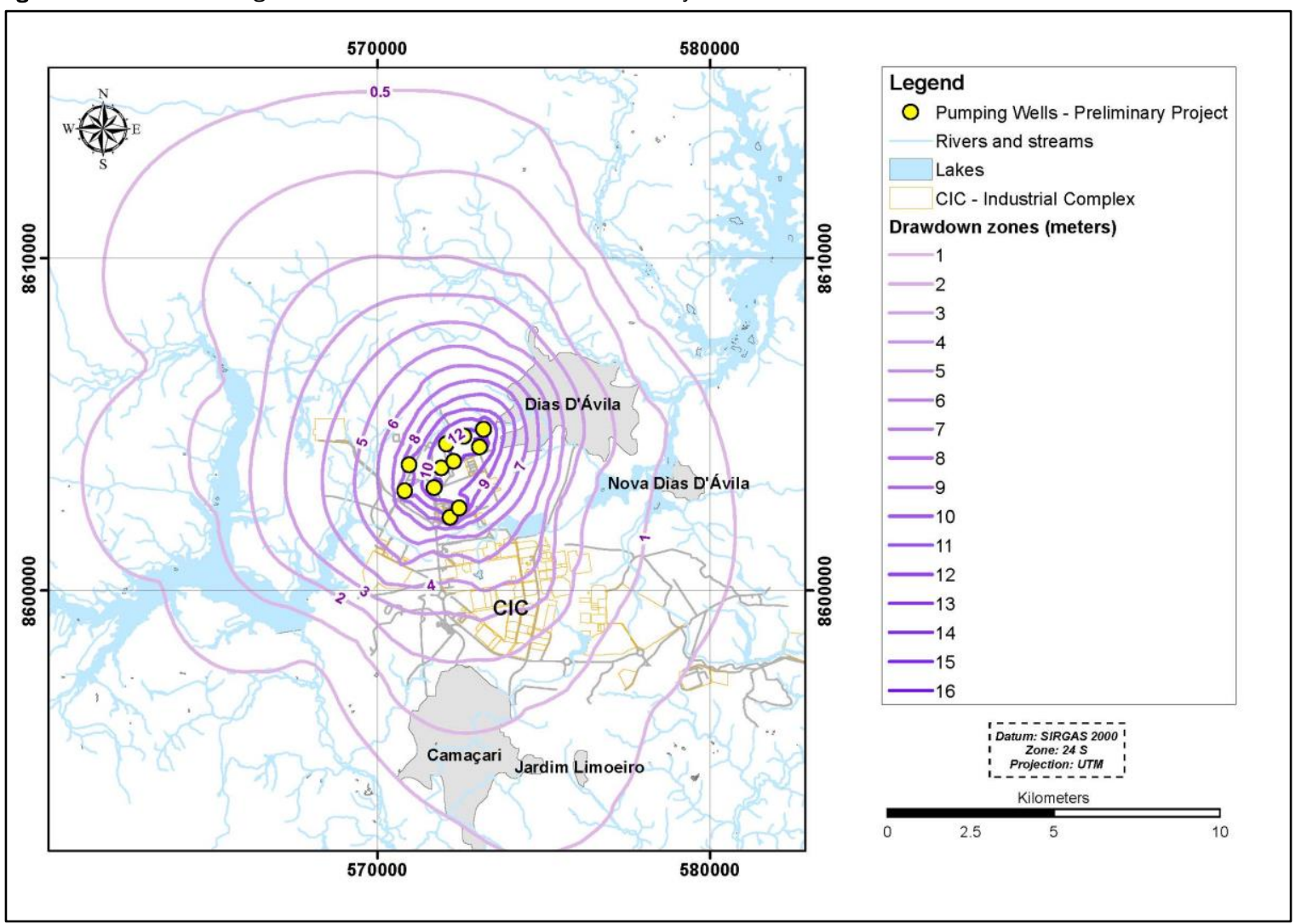




\section{HYDROGEOLOGICAL CRITERIA FOR GROUNDWATER WITHDRAWAL PERMISSION IN THE AREA OF THE CAMA- ÇARI INDUSTRIAL COMPLEX}

In practice, sustainable exploitation from groundwater is not only determined by the impacts of well capture and surrounding drawdown but also by rates of natural recharge and the evaluation of these dynamic processes in ecosystems as well as economic and social aspects, Zhou (2009).

Beyond the perspectives mentioned above, it is also crucial to identify processes and elements which would affect the quality conditions and quantity of water resources for management. Within this context water zoning has the function of mapping geographic elements and other criteria such as water quality, social and economic strategies and separate areas with similar issues. Therefore, water zoning should reflect societal needs concomitantly with sustainable environment aims. Although there is water zoning in the study area, the knowledge of the distribution of natural recharge would improve the understanding of water reserves and potentials and consequently make it an additional criterion to manage the area.

Therefore, the hydrogeological criteria rely on a new regional hydrogeological framework for the Marizal-São Sebastião aquifer system, including, new water zoning, new water reserves and potentials for each zone and classification of the water zones in terms of favorability for exploitation.

\subsection{New water zoning}

In order to manage water supply, water zone areas are created to ensure access to water resources by users in a sustainable way. In the CIC to define the new water zoning, the starting point was to take the entire RNFM domain area, from the previous 2013 map (Figure 3). Then, the extension of the deepest geological faults of the São Sebastião formation were used to define the water zones based on the compartmentalization of the Marizal-São Sebastiao aquifer.

First, it was necessary to take information from the geological map from CPRM, the Brazilian geological service company (CPRM, 1990), and from Lima (1999), for details of the Leandrinho and Camaçari faults, which are located in the center of the study area

Nevertheless, a variety of considerations were necessary to generate the new water zoning. For instance, to favor areas with the largest amount of physical data, obtained from the groundwater monitoring program, and to exclude areas without wells or hydraulic information. Moreover, areas where intensive industrial activities occur are more vulnerable to risks of pollution and should be subject to different criteria. As a result, water zone one (ZH-I) was delineated considering it borders an area with industrial purposes (Figure 7).

Considering the information from CICs Aquifer Intrinsic Vulnerability map from Santos (2010), water zone two (ZH-II) was separated from other areas.

In addition, water zones $\mathrm{ZH}-\mathrm{VII}$, which represents Camacari city, and ZH-III, representing Dias D'Avila city, were created to take into account the significant groundwater withdrawal from these cities, which causes interference in the CIC's groundwater management.

The other water zones were created only considering geological information to delimit their edges (Figure 7).

\subsection{Calculation of the groundwater recharge for each zone}

Table 1 presents the parameters involved in the calculation of groundwater recharge and the procedure for obtaining the necessary data.

Figure 7 - Water zoning proposed in this work

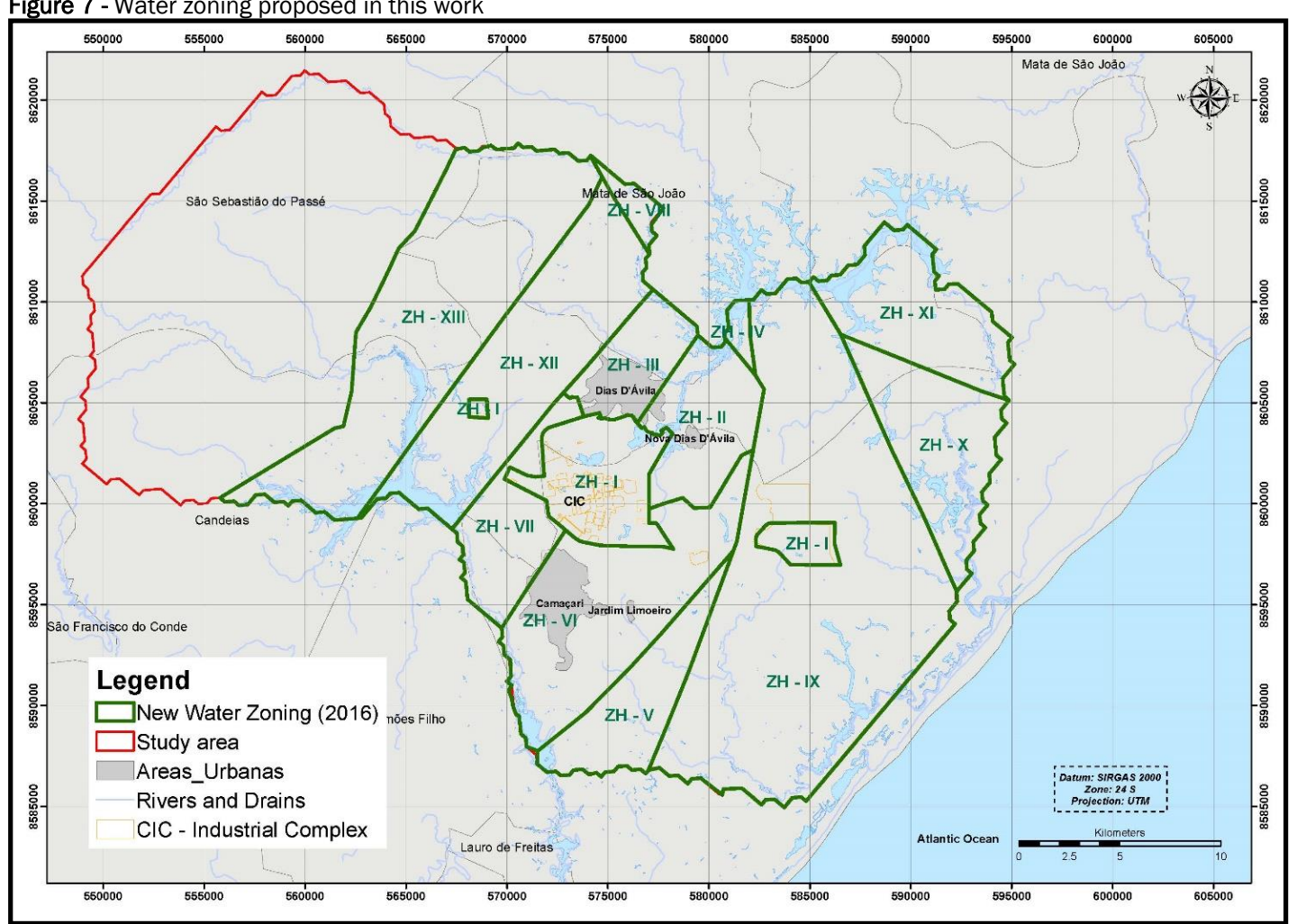


Table 1 - Parameters for calculation of groundwater recharge

\begin{tabular}{|c|c|c|c|}
\hline Parameters & Equation & & Necessary Information \\
\hline Recharge (R) & $\mathrm{R}=\mathrm{P}-\mathrm{EVT}-\mathrm{ES}$ & (1) & Uses the steady state water balance. \\
\hline Precipitation $(\mathrm{P})$ & & & $\begin{array}{l}\text { From eight (08) rainfall stations within the area of interest, given in Roedel } \\
\text { (2017). }\end{array}$ \\
\hline $\begin{array}{l}\text { Evapotranspiration } \\
\text { (EVT) }\end{array}$ & & & $\begin{array}{l}\text { Due to lack of local data, this work used the correlation "P" versus "EVT" from } \\
\text { the city of Salvador, weather station ( } 83229) \text { due to its proximity }(45 \mathrm{~km}) \text { to } \\
\text { the study area central position. }\end{array}$ \\
\hline Runoff (ES) & $\mathrm{ES}=\mathrm{C} \times \mathrm{P}$ & (2) & Calculated from precipitation and flow coefficient. \\
\hline Flow coefficient $(\mathrm{C})$ & $C C=1-\left(C_{1}^{\prime}+C_{2}^{\prime}+C_{3}^{\prime}\right)$ & (3) & $\begin{array}{l}\text { The values of coefficients } C \text { ' for each feature }(1=\text { slope, } 2=\text { soil and } 3=\text { land } \\
\text { coverage) were obtained from the IBGE (Brazilian Institute of Geography and } \\
\text { Statistics) and CPRM - Geological Service of Brazil maps, in the scales of } 1 \text { : } \\
1,000,000 \text { given in Roedel ( } 2017) \text {. }\end{array}$ \\
\hline
\end{tabular}

For the Marizal/São Sebastião aquifer system, precipitation is the main contributor of recharge and the most important attribute to evaluate the water potentialities in the region (LIMA, 1999; WATERLOO, 2003; SANTOS, 2010). It is accepted by several authors (WATERLOO, 2003; BREDEHOEFT, 2002; ZHOU, 2009; SANTOS, 2010) that the natural recharge is affected by external factors such as vegetation cover, slope of lands, rainfall and soil permeability.

To calculate the aquifer recharge based on the precipitation, Scanlon (2002) gives several methodologies, with being the water balance method being the most applied. This work performed a water balance aggregating data from precipitation, evapotranspiration and runoff, using tools from GIS (ArcGis, version 10.4) software, which offers map algebra operations between raster maps.

To begin with, precipitation data $(\mathrm{P})$ was utilized to construct the annual rainfall map by inverse distance interpolation creating equidistant isolines between stations.

Due to the lack of information related to evapotranspiration in this region, the correlation observed in the nearest station to the study area was used. Correlation rate between precipitation data $(\mathrm{P})$ and evapotranspiration (EVT) on the Salvador station is 0.64 ; therefore, the evapotranspiration map of the region considered $64 \%$ of the average annual precipitation from the 2006-2015 historical series. The calculation of surface runoff (Equation 2 in Table 1) depends on the runoff coefficient (C), which in turn depends on the attributes: soil slope (C'1), soil type $\left(C^{\prime} 2\right)$ and land coverage type $\left(C^{\prime} 3\right)$ represented by vegetation, urban pavement, and others. Using Equation 3 (Table 1) in ArcGis tools, we obtained the flow coefficient C. Applying Equation 2 together with the precipitation map resulted in the annual runoff map.

Finally, the annual recharge map was generated by applying the GIS tools and the water balance (Equation 1) to the maps of precipitation, evapotranspiration and runoff (Figure 8). The recharge map shows the highest recharge values coinciding with sandy soils, regions with wetlands and areas of extensive vegetation. On the other hand, low recharge values are shown in the northwestern portion of the map, matching with clayey soils. In some cases, pixel values registered were negative, which represents a limitation and uncertainty inherent to this method.

Figure 8 - Annual Recharge on Study Area

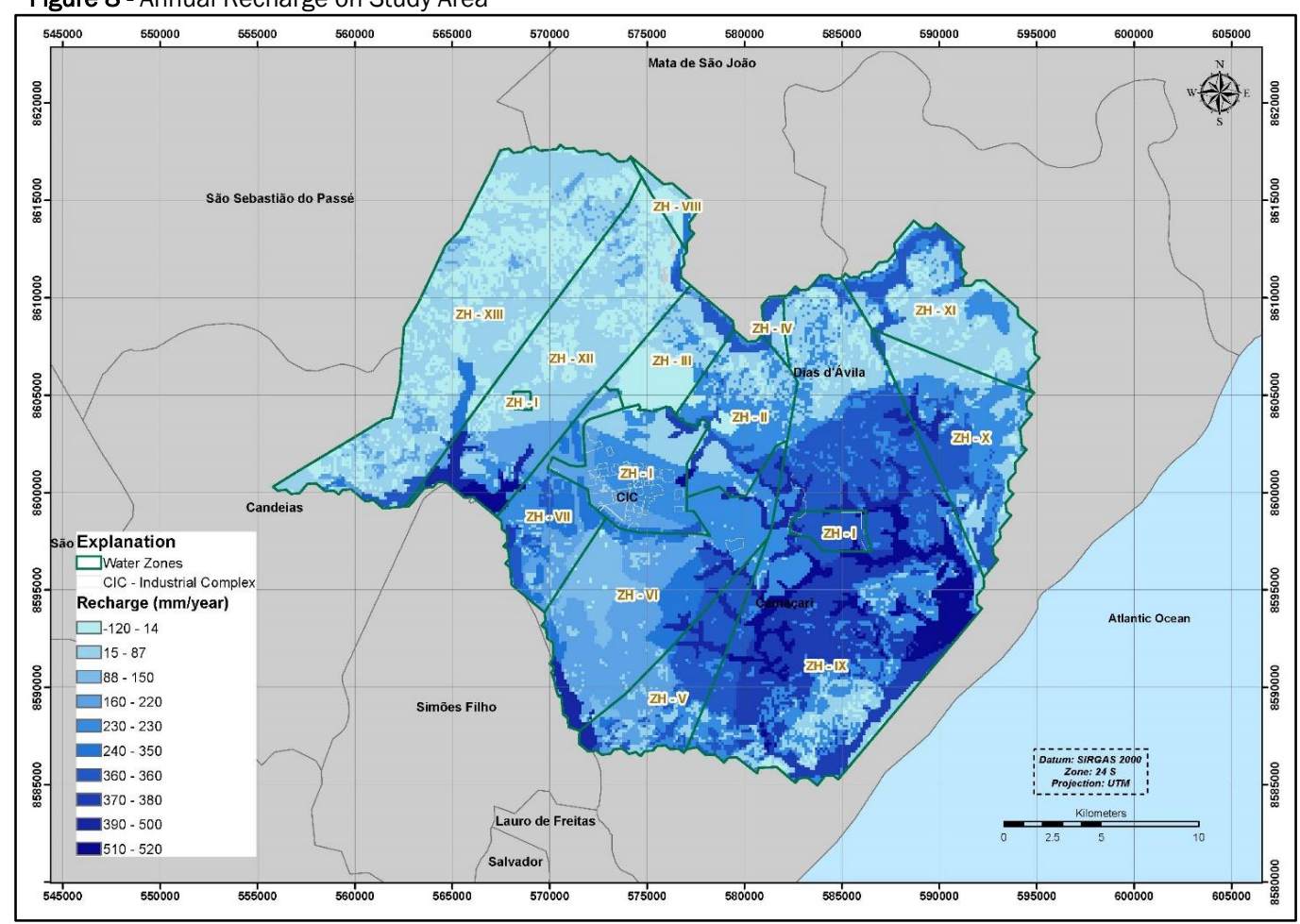


Regardless of the limitations observed in the method presented to obtain recharge estimation, it is important to consider that this methodology is a significant improvement if compared to previous recharge estimation carried out by other authors. The first attempt to estimate recharge in this region used flow rate data measured in the Jacuipe river, which resulted in a calculation of roughly $675 \mathrm{~mm} /$ year (Hidroconsult 1990, Waterloo 2003). Within a few years, Tucci (2009) estimated a more realistic number, which was tested in the regional model (RNFM), obtaining a recharge rate between 220 and $350 \mathrm{~mm} /$ year. Nonetheless, the major advantage of the me- thodology presented in this work was to define recharge values for different managing zones, which is useful to calculate water availability by zones, and, consequently, be useful as an initial management tool, before the application of the RNFM model. Furthermore, the results obtained were also used to improve modeling calibration and consequently improve further exploitation forecasts.

Table 2 presents in detail recharge statistical data for each water zone. The recharge average value estimated in the area of interest was between $53-296$ ( $\mathrm{mm} /$ year).

Table 2 - Recharges values for each water zone ( $\mathrm{mm} /$ year)

\begin{tabular}{cccc}
\hline Water Zones & Maximum & Average & Median \\
\hline ZH - I & 510 & 226 & 220 \\
ZH - II & 362 & 78 & 80 \\
ZH - III & 508 & 184 & 219 \\
ZH - IV & 352 & 190 & 81 \\
ZH - V & 496 & 281 & 346 \\
ZH - VI & 494 & 240 & 211 \\
ZH - VII & 520 & 243 & 219 \\
ZH - VIII & 346 & 90 & 13 \\
ZH - IX & 520 & 296 & 356 \\
ZH - X & 498 & 212 & 219 \\
ZH - XI & 352 & 122 & 81 \\
ZH - XII & 519 & 107 & 79 \\
ZH - XIII & 485 & 53 & 77 \\
\hline Intervals & $\mathbf{3 5 2 - 5 2 0}$ & $\mathbf{5 3 - 2 9 6}$ & $\mathbf{1 3 - 3 5 6}$ \\
\hline
\end{tabular}

\subsection{Calculation of the groundwater reserves and potentiality for each zone}

To calculate the groundwater reserves and potentiality for each water zone, this work used the hydraulic parameters obtained from the CIC's well network monitoring program, besides recharge rates previously obtained. Detailed information about the values of hydraulic parameters, such as, operating flow, maximum flow rates from aquifer tests, maximum drawdowns, specific capacity, transmissivity and hydraulic conductivity can be found in Roedel (2017). The definition of all parameters involved in the calculation of permanent reserves, regulatory reserves, and water potential per water zone are in Table 3.

Table 3 - Parameters for calculation of groundwater reserves and potentiality

\begin{tabular}{|c|c|c|c|}
\hline Parameters & Equation & & Necessary Information \\
\hline Permanent reserve, $R_{p}\left(m^{3}\right)$ & $R_{p}=(A h S)+\left(A b \eta_{\mathrm{ef}}\right)$ & (4) & $\begin{array}{l}\text { Equation applied to free and confined aquifers, Costa } \\
\text { (1998). }\end{array}$ \\
\hline \multicolumn{4}{|l|}{$\begin{array}{l}\text { Where, } \\
\text { Aquifer occurrence area, } \mathrm{A}\left(\mathrm{m}^{2}\right)\end{array}$} \\
\hline Confined aquifer potentiometric head, $\mathrm{h}(\mathrm{m})$ & & & $\begin{array}{l}\text { Uses the averaged potentiometric head. } h=\text { topogra- } \\
\text { phic height - pressure of water level }(m) \text {. }\end{array}$ \\
\hline Aquifer storage coefficient, S (-) & & & $\begin{array}{l}\text { Averaged value between } 10^{-5} \text { e } 10^{-4} \text {, Waterloo, } \\
\text { (2003). }\end{array}$ \\
\hline Aquifer saturated thickness, b (m) & & & $\begin{array}{l}\text { The calculation of thickness of aquifer layer, in each } \\
\text { water zone, took as a reference the well maximum de- } \\
\text { pth, neglecting volumes stored in clays. }\end{array}$ \\
\hline Aquifer effective porosity, $\eta_{\text {ef }}\left(\mathrm{m}^{3} / \mathrm{m}^{3}\right)$ & & & $\begin{array}{l}\text { Taken as } \eta_{\text {ef }}=0,21 \text { (Johnson, 1967), for fine sandy } \\
\text { sediments. }\end{array}$ \\
\hline Aquifer regulatory reserves, $\mathrm{R}_{\mathrm{r}}$ (m³/year) & $R_{r}=A \Delta R$ & (6) & $\begin{array}{l}\text { Calculated based on the annual aquifer recharges, by } \\
\text { water zone, where } \Delta R \text { is the aquifer annual recharge } \\
\text { (m/year) obtained through water balance. }\end{array}$ \\
\hline Aquifer potentiality, $\mathrm{P}_{\mathrm{o}}\left(\mathrm{m}^{3} /\right.$ year) & $P_{o}=R_{r}+0.006 * R_{p}$ & (7) & $\begin{array}{l}\text { Calculation recommended by Cetrel (2012). As it is a } \\
\text { sedimentary aquifer with high availability and exten- } \\
\text { sive area available to direct recharge, the authors ad- } \\
\text { mitted the use of a small portion of the permanent } \\
\text { reserve as exploitable. }\end{array}$ \\
\hline
\end{tabular}


The definition of groundwater permanent reserves $\left(R_{p}\right)$ is the amount of water storage in the aquifer which does not change due to seasonal fluctuation of the hydraulic head (Costa, 1998). On the other hand, regulatory reserves $\left(R_{r}\right)$ refer to the amount of water storage in the aquifer due to seasonal recharge and can be impacted by rainfall seasons. The knowledge of these concepts is important to achieve sustainable and conservative volumes to be exploited from aquifers.

Hence, to calculate the water potentiality $\left(P_{0}\right)$ this work considered contributions of water partially from rainfall seasons and other small amount, approximately $0.6 \%$ from groundwater permanent reserves $\left(R_{p}\right)$. It is important to point out that, though the calculation of aquifer potentiality seems controver- sial for using a small portion of permanent reserve, the determination of sustainable volumes of exploitation also takes into account local economic and social strategies, aiming at a balance between stakeholders. Therefore, this work conducted its assessment considering technical and economic aspects.

Table 4 summarizes the results for groundwater reserves, both, permanent $\left(R_{p}\right)$ and regulatory $\left(R_{r}\right)$ and water potentiality (Po) for each water zone. The symbol (NA) indicates no information from production wells to estimate the saturated aquifer thickness necessary to calculate $\left(R_{p}\right)$. The values in Table 4 are very close to the values obtained by other authors (LIMA 1999; ANA, 2005).

$\underline{\text { Table } 4 \text { - Long term and renewable water resources and potentiality for each water zone }}$

\begin{tabular}{|c|c|c|c|c|}
\hline Water Zone & Area $\left(m^{2}\right)$ & $\begin{array}{c}\text { Permanent reserve } \\
\qquad R_{p}\left(m^{3}\right)\end{array}$ & $\begin{array}{l}\text { Regulatory reserve } \\
\qquad R_{r}\left(m^{3} / \text { year) }\right.\end{array}$ & $\begin{array}{l}\text { Potentiality } \\
\text { Po ( } m^{3} / \text { year) }\end{array}$ \\
\hline ZH - I & $4.16 \mathrm{E}+07$ & $1.23 \mathrm{E}+09$ & $9.41 \mathrm{E}+06$ & $1.68 \mathrm{E}+07$ \\
\hline $\mathrm{ZH}-\mathrm{II}$ & $2.21 \mathrm{E}+07$ & $4.35 E+08$ & $1.73 E+06$ & $4.35 E+06$ \\
\hline ZH - III & $3.39 E+07$ & $9.14 \mathrm{E}+08$ & $6.23 E+06$ & $1.17 \mathrm{E}+07$ \\
\hline ZH - IV & $3.21 E+06$ & NA & $6.09 E+05$ & $6.09 E+05$ \\
\hline $\mathrm{ZH}-\mathrm{V}$ & $3.19 \mathrm{E}+07$ & $1.37 \mathrm{E}+09$ & $8.98 \mathrm{E}+06$ & $1.72 \mathrm{E}+07$ \\
\hline $\mathrm{ZH}-\mathrm{VI}$ & $7.49 \mathrm{E}+07$ & $3.60 E+09$ & $1.80 \mathrm{E}+07$ & $3.96 \mathrm{E}+07$ \\
\hline ZH - VII & $2.95 \mathrm{E}+07$ & $1.05 E+09$ & $7.17 \mathrm{E}+06$ & $1.35 E+07$ \\
\hline ZH - VIII & $4.73 E+06$ & NA & $4.26 \mathrm{E}+05$ & $4.26 \mathrm{E}+05$ \\
\hline ZH - IX & $2.02 E+08$ & $9.85 E+09$ & $5.97 \mathrm{E}+07$ & $1.19 E+08$ \\
\hline $\mathrm{ZH}-\mathrm{X}$ & $4.44 \mathrm{E}+07$ & NA & $9.42 \mathrm{E}+06$ & $9.42 E+06$ \\
\hline $\mathrm{ZH}-\mathrm{XI}$ & $4.32 \mathrm{E}+07$ & NA & $5.26 \mathrm{E}+06$ & $5.26 \mathrm{E}+06$ \\
\hline ZH - XII & $7.83 \mathrm{E}+07$ & $1.79 \mathrm{E}+09$ & $8.37 \mathrm{E}+06$ & $1.91 \mathrm{E}+07$ \\
\hline ZH - XIII & $1.15 \mathrm{E}+08$ & NA & $6.11 E+06$ & $6.11 E+06$ \\
\hline TOTAL & $7.25 \mathrm{E}+08$ & $2.02 E+10$ & $1.41 \mathrm{E}+08$ & $2.63 E+08$ \\
\hline \multicolumn{2}{|c|}{ Lima (1999) } & $6.0 \mathrm{E}+11$ & $5.00 E+08$ & $5.0 \mathrm{E}+08$ \\
\hline \multicolumn{2}{|c|}{ ANA (2005) } & & $2.49 E+09$ & $4.9 \mathrm{E}+08$ \\
\hline
\end{tabular}

Note: NA - No available.

Table 5 shows potentiality of the water zone (Poeffective) for each water zone in CIC's region. This was calculated by discounting the water volumes already compromised from previous licenses (granted until 2015) from the groundwater potentiality (Po). A similar approach has already been applied in the Distrito Federal region (Castro, 2011). To sum up, this work assumes that the calculation of potentiality of the water zone (Poeffective) encompasses not only characteristics of the confined aquifer and natural recharge estimation, but also local strategies of sustainable management of reserves.

For this purpose, the parameter effective potentiality of the water zone (Poeffective) should be the first criterion used by groundwater managers, responsible for issuing water withdrawal permission in the $\mathrm{CIC}$. 
Table 5 - Effective Potentiality per Water Zone

\begin{tabular}{|c|c|c|c|c|c|}
\hline Water Zone & $\begin{array}{l}\text { Potentiality (Po) } \\
\left(\mathrm{m}^{3} / \text { year }\right)\end{array}$ & $\begin{array}{l}\text { Quantity } \\
\text { of wells }\end{array}$ & $\begin{array}{c}Q \text { compromised average } \\
\left(\mathrm{m}^{3} / \text { year }\right)\end{array}$ & $\begin{array}{c}\text { Effective Potentiality (Poeffective) } \\
\text { until } 2015\left(\mathrm{~m}^{3} / \text { year) }\right.\end{array}$ & Actual Condition \\
\hline $\mathrm{ZH}-\mathrm{I}$ & $16,538,062$ & 26 & $8,060,514$ & $8,739,194$ & excellent water reserve \\
\hline $\mathrm{ZH}-\mathrm{II}$ & $4,379,887$ & 2 & 74,810 & $4,270,398$ & excellent water reserve \\
\hline $\mathrm{ZH}-\mathrm{III}$ & $12,917,828$ & 8 & $6,250,961$ & $5,466,257$ & excellent water reserve \\
\hline ZH - IV & 260,091 & - & - & 609,397 & small area \\
\hline $\begin{array}{l}\mathrm{ZH}-\mathrm{V} \\
\mathrm{ZH}-\mathrm{VI}\end{array}$ & $\begin{array}{l}19.284 .970 \\
37,367,118\end{array}$ & $\begin{array}{c}3 \\
20\end{array}$ & $\begin{array}{c}3.997 .276 \\
29,107,728\end{array}$ & $\begin{array}{l}13.225 .134 \\
10,445,168\end{array}$ & $\begin{array}{l}\text { excellent water reserve } \\
\text { excellent water reserve }\end{array}$ \\
\hline $\mathrm{ZH}-\mathrm{VII}$ & $12,761,479$ & 17 & $21,531,554$ & $-8,057,386$ & $\begin{array}{c}\text { no water available for conser- } \\
\text { vative and sustainable use }\end{array}$ \\
\hline ZH - VIII & 61,516 & - & - & 426,387 & small area \\
\hline $\mathrm{ZH}-\mathrm{IX}$ & $130,958,004$ & 1 & 43,800 & $118,727,445$ & excellent water reserve \\
\hline $\mathrm{ZH}-\mathrm{X}$ & $9,719,089$ & - & - & $9,415,818$ & excellent water reserve \\
\hline $\mathrm{ZH}-\mathrm{XI}$ & $3,497,540$ & - & - & $5,262,491$ & excellent water reserve \\
\hline $\mathrm{ZH}-\mathrm{XII}$ & $16,909,162$ & 7 & $4,502,903$ & $14,587,593$ & excellent water reserve \\
\hline \multirow[t]{2}{*}{ ZH - XIII } & $8,890,482$ & & - & $6,113,305$ & excellent water reserve \\
\hline & & & & Sum $=189,231,202$ & \\
\hline
\end{tabular}

From Table 5, ZH-VII no longer has water available for conservative and sustainable exploitation and, therefore, deserves greater attention and control, especially for long-term exploitation. From the point of view of the methodology proposed here, which seeks sustainable groundwater use, water zone $\mathrm{ZH}-\mathrm{VII}$ should restrict exploitation for new users and recommend reduction of flow rates from current pumping wells.

Potentiality results obtained for ZH-VII highlight interesting questions, such as whether storage in the semiconfined aquifer has been affected by current pumping rates. To demonstrate if the criteria based on potentiality can be used as the first step in sustainable groundwater management, a real case study was undertaken, as shown in subsequent sections

\subsection{Water zone classification}

Although most of the water zones presented good volumes of potentiality, to finally classify water zones, subjective aspects were incorporated in this assessment. Environmental factors of quality and aquifer intrinsic vulnerability (Santos, 2010) were considered as premises of aquifer conservative use and sustainability. The favorability factors, which encompass potentiality and the above-mentioned aspects, are the following: low favorability, favorable and high favorability. Table 6 shows a summary of the conditions for giving groundwater withdrawal permission in the region of interest.

Table 6 - Favorability for exploitation for each water zone

\begin{tabular}{|c|c|c|}
\hline Water Zone & Description & Favorability \\
\hline $\mathrm{ZH}-\mathrm{I}$ & $\begin{array}{l}\text { It has good exploitation potentialHowever, its water has high risk of contamination by indus- } \\
\text { trial chemical and petrochemical processes. }\end{array}$ & Unfavorable \\
\hline $\mathrm{ZH}-\mathrm{II}$ & $\begin{array}{l}\text { It has good exploitation potential. However, aquifer in this area has high intrinsic vulnerabi- } \\
\text { lity (Santos 2010). }\end{array}$ & Low \\
\hline $\mathrm{ZH}-\mathrm{III}$ & $\begin{array}{l}\text { It has low exploitation potential. Despite volumes of water available to be exploited, interac- } \\
\text { tions with surface water are relatively high. Consequently has low favorability to exploitation. }\end{array}$ & Low \\
\hline $\mathrm{ZH}-\mathrm{IV}$ & $\begin{array}{l}\text { It has smaller exploitation potential due to low extension and volumes of water. Fault zones } \\
\text { can represent geological instability. Aquifer has high intrinsic vulnerability Santos 2010). }\end{array}$ & Low \\
\hline $\mathrm{ZH}-\mathrm{V}$ & $\begin{array}{l}\text { Exploitable zone in need of control. Has }>50 \% \text { of its water discharging to wells. Recommen- } \\
\text { ded to reduce exploitation. }\end{array}$ & Low \\
\hline $\mathrm{ZH}-\mathrm{VI}$ & $\begin{array}{l}\text { Exploitable zone in need of control. Has }>50 \% \text { of its water discharging to wells. Recommen- } \\
\text { ded to reduce exploitation. }\end{array}$ & Low \\
\hline $\mathrm{ZH}-\mathrm{VII}$ & $\begin{array}{l}\text { Exploitable zone in need of control. Has high density of wells. Natural recharge highly com- } \\
\text { promised, recommended to reduce the exploitation. }\end{array}$ & Unfavorable \\
\hline $\mathrm{ZH}-\mathrm{VIII}$ & $\begin{array}{l}\text { It has smaller exploitation potential due to its low extension and volumes of water. Fault zo- } \\
\text { nes can represent geological instability. Exploitable zone requires additional studies to cal- } \\
\text { culate water reserves. }\end{array}$ & Low \\
\hline $\mathrm{ZH}-\mathrm{IX}$ & Exploitable zone with potential for expansion. & High \\
\hline $\mathrm{ZH}-\mathrm{X}$ & $\begin{array}{l}\text { Exploitable zone requires additional studies to calculate water reserves. There are no data } \\
\text { available to better estimate potentiality of exploitation. }\end{array}$ & Favorable \\
\hline $\mathrm{ZH}-\mathrm{XI}$ & Partially exploitable zone, moderate vulnerability. & Favorable \\
\hline $\mathrm{ZH}-\mathrm{XII}$ & Exploitable zone with potential for expansion. & High \\
\hline $\mathrm{ZH}-\mathrm{XIII}$ & $\begin{array}{l}\text { Exploitable zone with potential for expansion. It requires additional studies to calculate wa- } \\
\text { ter reserves. There are no data available to estimate potentiality of exploitation. }\end{array}$ & High \\
\hline
\end{tabular}


Once, the water zones and their groundwater availability have been established, this work proposes a flowchart for CIC's groundwater managers to develop the technical evaluation of withdrawal permission. It proposes two stages for evaluation, the first before project implementation and the other, after pumping well installation. Figure 9 presents the two stages for evaluation of a groundwater withdrawal permission.
It is important to note, that the proposed methodology considers water zoning premises as the first stage of evaluation followed by assessment of the hydrogeological database and then simulations of different scenarios of pumping in this region. Moreover, this methodology is a dynamic process, which is continuously updated with new data collected by the monitoring program.

Figure 9 - Evaluation of the groundwater withdrawal permission (before and after well drilling)
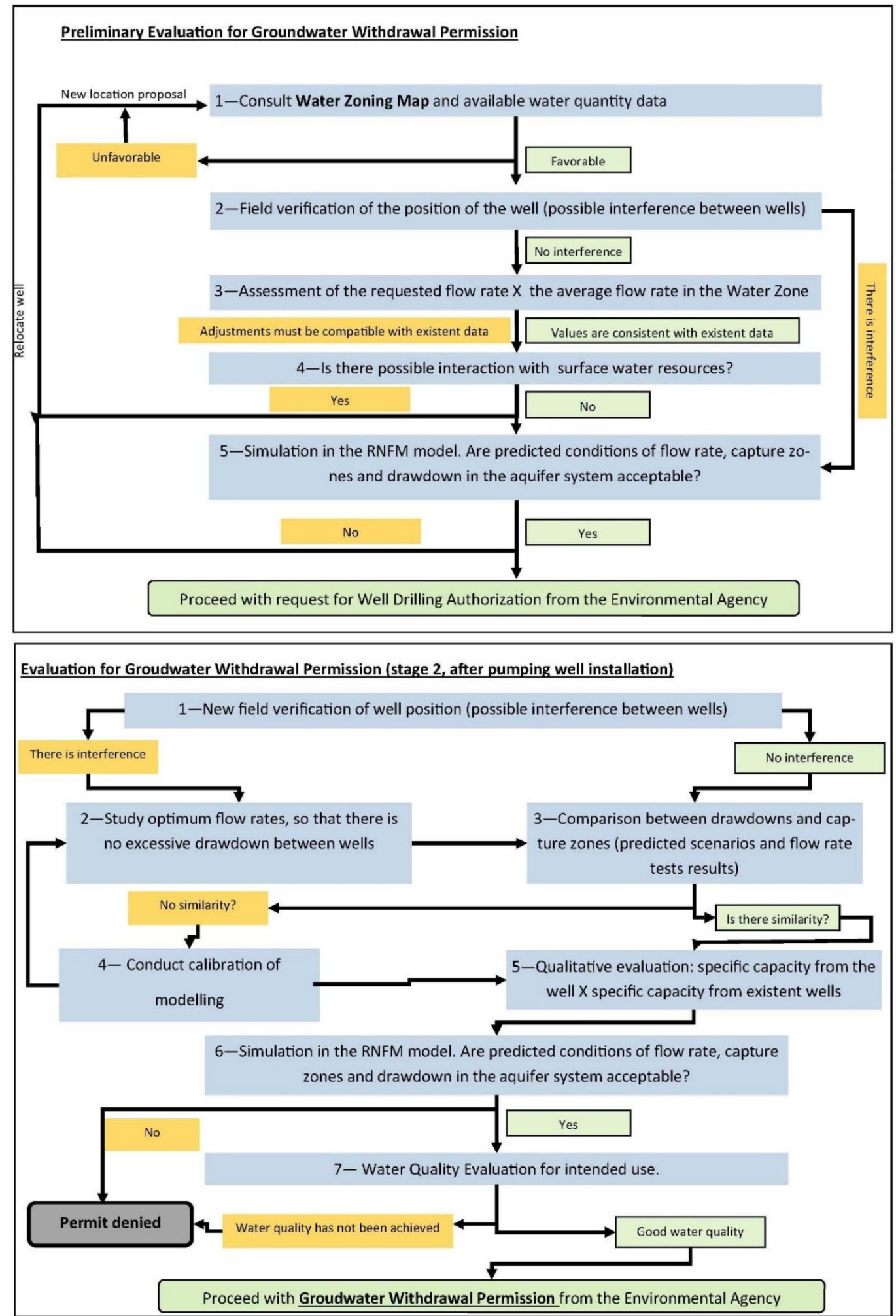
The first stage ends with the drilling request to the competent state agency. In case the decision is favorable, in the second stage, the data obtained from the aquifer-pumping test will serve to compare with the known hydrodynamic data for the water zone aquifer (K, S, etc.) and with the specific capacity of other wells in that water zone. At this stage, it is necessary to verify using the RNFM, the possibility of interference between wells and to simulate new capture zones and drawdown. Another assessment that should be conducted by managers is the evaluation of whether impacts are occurring in the groundwater storage through observed hydraulic heads in piezometric wells.

\section{TESTING THE HYDROGEOLOGICAL CRITERIA FOR GROUNDWATER WITHDRAWAL PERMISSION: CASE STUDY IN THE CAMAÇARI INDUSTRIAL COMPLEX AREA}

The case study to test the proposed methodology is the operation of the 11-wells field located in the northern region of CIC's area (Fig. 4).

Table 7 presents data from the pumping tests of the 11-wells field, regarding the parameters: maximum flow, drawdown, and specific capacity, obtained in the year 2004. For comparison, we present the same parameters obtained from the 11-wells monitoring program, in the year 2015.

Table 7 - Data for the 11-wells field, from the test (year 2004) and from monitoring (year 2015)

\begin{tabular}{cccccccc}
\hline Well & $\begin{array}{c}\text { Depth } \\
(\mathrm{m})\end{array}$ & $\begin{array}{c}\text { Test maximum } \\
\text { flow }- \\
\mathrm{Q}\left(\mathrm{m}^{3} / \mathrm{h}\right)\end{array}$ & $\begin{array}{c}\text { Test maximum } \\
\text { drawdown }-\mathrm{s} \\
(\mathrm{m})\end{array}$ & $\begin{array}{c}\text { Test specific } \\
\text { capacity }- \\
\mathbf{Q} / \mathrm{s}\left(\mathrm{m}^{3} / \mathrm{h} / \mathrm{m}\right)\end{array}$ & $\begin{array}{c}\text { Monitored } \\
\text { average flow }- \\
2015\left(\mathrm{~m}^{3} / \mathrm{h}\right)\end{array}$ & $\begin{array}{c}\text { Monitored average } \\
\text { drawdown }-2015 \\
(\mathrm{~m})\end{array}$ & $\begin{array}{c}\text { Effective spe- } \\
\text { cific capacity } \\
-\mathrm{Q} / \mathrm{s} \\
\left(\mathrm{m}^{3} / \mathrm{h} / \mathrm{m}\right)\end{array}$ \\
\hline PP-B/009 & 450.8 & 222.0 & 39.1 & 5.68 & 186.5 & 50.0 & 3.73 \\
PP-B/010 & 450.0 & 129.2 & 22.2 & 5.82 & 181.2 & 60.0 & 3.02 \\
PP-B/011 & 480.0 & 270.0 & 32.2 & 8.39 & 166.3 & 85.0 & 1.96 \\
PP-B/012 & 453.8 & 250.0 & 35.7 & 7.01 & 171.5 & 75.0 & 2.29 \\
PP-B/013 & 450.0 & 250.0 & 35.4 & 7.07 & 202.0 & 80.0 & 2.53 \\
PP-B/014 & 449.4 & 250.0 & 51.9 & 4.82 & 186.3 & 90.0 & 2.07 \\
PP-B/015 & 450.1 & 250.0 & 34.4 & 7.27 & 141.5 & 70.0 & 2.02 \\
PP-B/016 & 450.1 & 250.0 & 33.1 & 6.91 & 190.5 & 80.0 & 2.38 \\
PP-B/017 & 447.6 & 250.0 & 27.4 & 8.76 & 177.3 & 80.0 & 2.22 \\
PP-B/018 & 450.9 & 250.0 & 40.0 & 5.92 & 176.3 & 75.0 & 2.35 \\
PP-B/019 & 449.5 & 250.0 & 38.6 & 6.48 & 190.7 & 85.0 & 2.24 \\
\hline
\end{tabular}

Before the installation of wells in 2004, pumping scenarios were simulated in the RNFM model indicating interference between wells, in spite of that, results presented by the RNFM model were not enough to justify changes in the project. The RNFM model predicted drawdown and capture in the aquifer system but, due to uncertainties inherent to this method, there was no observed evidence of depletion of storage in the aquifer system.

After the installation of pumping wells, the largest expected drawdown from the pumping test was $40 \mathrm{~m}$ (Table 7). However, in 2009, when pumping wells started to pump, the largest drawdown observed was $90 \mathrm{~m}$, indicating that the occurrence of interference between capture zone of wells was much more than expected. The aquifer system presented signs of storage depletion, which was observed in the hydraulic heads, measured in surrounding piezometric wells. The possible reasons for such vulnerability were due to uncertainties inherent to the RNFM model, which needs frequent calibration efforts in order to improve further forecasts.
The specific capacity of the well is often obtained by dividing pumping rate $(\mathrm{Q})$ by the drawdown in the pumping well (s) and it is a good way to measure the capacity pumping wells have to exploit good volumes of water from an aquifer system. In CIC's region, pumping wells which present good performance usually show values of roughly $5 \mathrm{~m}^{3} / \mathrm{h} / \mathrm{m}$. Nonetheless, the effective range obtained for pumping wells in this case study was from 1.96 to $3.73 \mathrm{~m}^{3} / \mathrm{h} / \mathrm{m}$. Consequently, the necessary reduction of the flow rates of the installed 11 pumping wells compromised the groundwater volumes requested by the company.

Figure 10 presents the projected well locations (year 2004) as yellow dots, and the final drilling locations as red dots. Figure 10 also indicates the new water zoning from this work.

Table 8 summarizes the main problems of the 11 pumping well locations regarding the new water zoning and possible recommendations using additional water zone criteria before other assessments. 
Figure 10 - Proposed and final location of the 11-wells field (year 2004) in comparison with the preliminary project and with the new water zoning

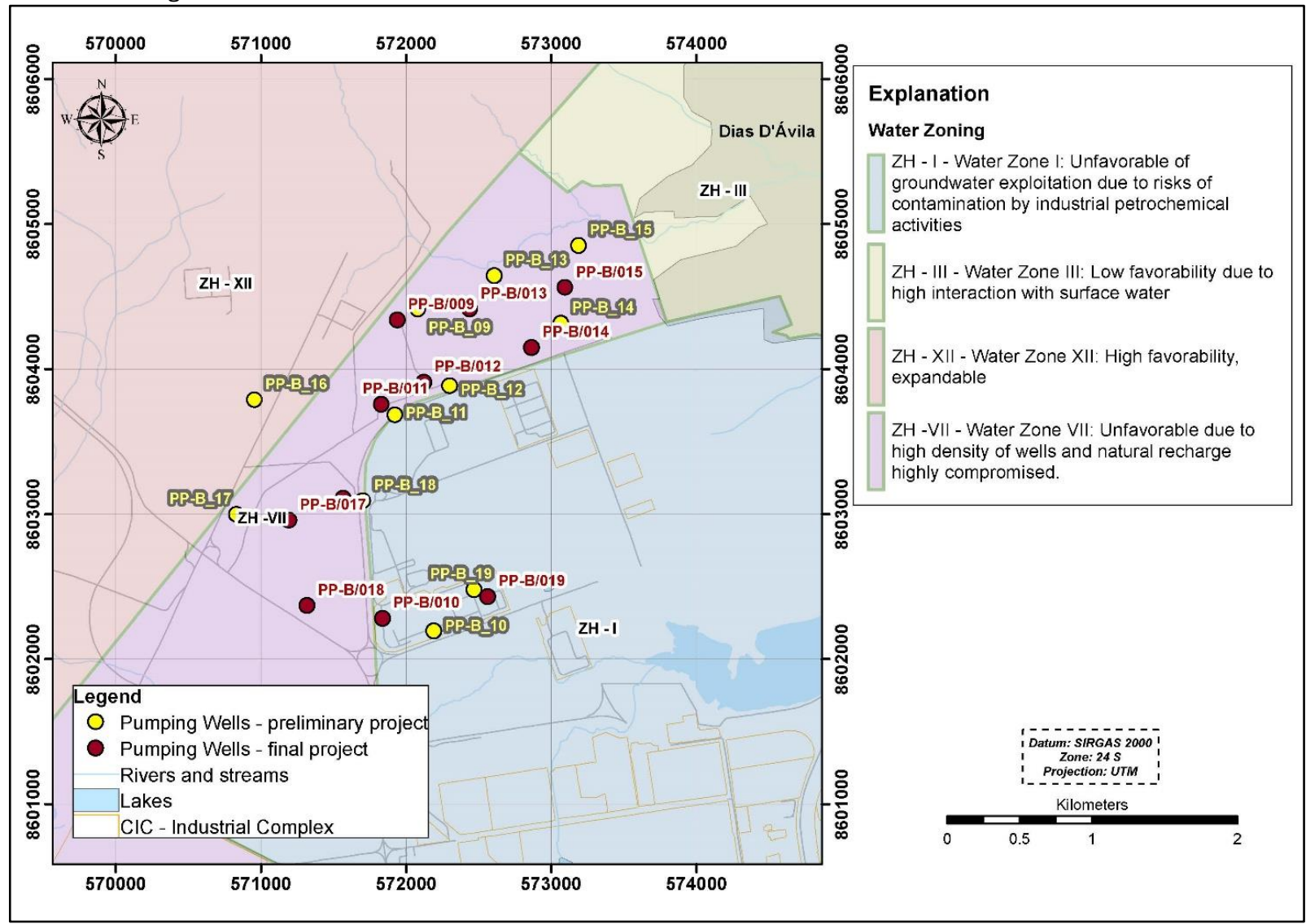

Table 8 - Main problems with the location of the 11-wells field and recommendations

\begin{tabular}{|c|c|c|c|}
\hline Water zone & Situation & Well Location & Recommendation using the new criteria \\
\hline $\mathrm{ZH}-\mathrm{I}$ & Risk of contamination & PP-B/010 and PP-B/019 & Relocation to another water zone (ZH-XII) \\
\hline $\mathrm{ZH}-\mathrm{VII}$ & $\begin{array}{l}\text { Unfavorable for exploitation. } \\
\text { High density of wells and natu- } \\
\text { ral recharge compromised. }\end{array}$ & $\begin{array}{l}09 \text { pumping wells located in } \\
\text { the same zone. }\end{array}$ & Relocation to another water zone ( $\mathrm{ZH}-\mathrm{XII})$ \\
\hline $\mathrm{ZH}-\mathrm{XII}$ & Excellent water reserve & available for new projects. & - \\
\hline
\end{tabular}

Applying water zoning premises to initially assess the preliminary project would have been useful in providing arguments to make changes in the project before its execution. Water zoning is an interesting tool which uses different approaches on the subject (quantitative and qualitative evaluation of the aquifer system and social and economic approaches for water demand) to help managers to make decisions. As a result, relocating or redistributing the wells among water zones $\mathrm{ZH}-\mathrm{VII}$ and $\mathrm{ZH}-\mathrm{XII}$ would be the most appropriate recommendation, especially because water zone ZH-XII has better water potential for exploitation (Figure 5).

Thereafter, using the RNFM comes at the second stage in order to indicate a better distribution of the wells in the area and eliminate interference between wells. The CIC's RNFM model, even with uncertainties, is reliable and has made good predictions for this region.

To conclude, the evaluation of the RNFM modeling in 2004, proposed only installing wells with a more spaced configuration. However, the RNFM itself would not be enough to predict the intensive effect caused by the new pumping network in the aquifer system. Nevertheless, using the hydrogeological criteria from this work, the recommendation is more adequate, as it proposes relocating wells to a zone with better water potential for exploitation. Assessment by using water zoning criteria together with the RNFM model is a more reliable methodology to improve groundwater management in this region.

\section{CONCLUSIONS}

The hydrogeological criteria suggested in this paper for requesting groundwater withdrawal permission are consistent with sustainable groundwater management, as demonstrated in the case study, as it considers the following parameters: total and effective water potentiality; favorability of exploitation; qualitative assessment of hydraulic parameters; surface drainage base flow, well flow obtained from pumping tests; and hydrochemical quality of the aquifer water.

The parameters of water potentiality and exploitation favorability for each water zone were calculated to incorporate characteristics of local natural recharge, qualitative hydrogeological and geochemical characteristics and local strategies of sustai- 
nable management of reserves; condensed together on the water zoning map. Once the water zoning has been defined, the RNFM helps to define capture zones and drawdowns between pumping systems in detail. The RNFM is also used to periodically calibrate the water balance between zones and help review the favorability for groundwater exploitation.

The RNFM is a useful tool for the management of groundwater resources; however, the model calibration needs constant updating with new hydrogeological field data from new well drilling and tests. Simulations with the RNFM considering real field data (after drilling) will help to obtain new capture zones and withdrawal conditions.

The hydrogeological criteria developed in this work based on water zoning, potentialities and classification of favorability, along with simulations from the RNFM offer better guidance to the groundwater resources managers of the Camaçari Industrial Complex. This approach is also appropriate to be applied in other areas which present similar issues. Changes in the proposed well location, depths and filter section positioning, among other factors, can significantly interfere with the results. The new approach to the granting process will enable sustainable management of the regional groundwater resources.

\section{REFERENCES}

ANA. Conjuntura dos recursos hídricos: informe 2014. Brasília, 2015. Available at: http://conjuntura.ana.gov.br/docs/conj2014 inf.pdf. Consulted on: 29 Abr. 2019

BAHIA. Secretaria da Indústria, Comércio e Mineração do Estado da Bahia - SICM. Plano Diretor do Polo Industrial de Camaçari. Salvador, BA: Governo do Estado da Bahia, 2013.

BAHIA. Secretaria de Infraestrutura Hídrica e Saneamento. Plano de abastecimento de água da Região Metropolitana de Salvador, Santo Amaro e Saubara. Relatório Parcial Fase I TOMO II - Estudos Básicos, v.2, cap.1. Salvador, BA: Governo do Estado da Bahia, 2016.

Bredehoeft, J.D.The water budget myth revisited: why hydrogeologists model. Ground Water, 40, 340-345, 2002. https://doi.org/10.1111/j.1745-6584.2002.tb02511.x

CASTRO J.E. 2007. Water Governance in the twentieth-first century. Ambiente e Sociedade, v. 10, n. 2, 2007. https://doi.org/10.1590/S1414-753X2007000200007

CASTRO C. M.; MELLO, R. M. Explotação de água subterrânea no Distrito Federal. In: SIMPÓSIO BRASILEIRO DE RECURSOS HÍDRICOS, 19., 2011. [Anais...]. Maceió, 2011.

CETREL. Plano de gestão integrada e zoneamento dos recursos hídricos no polo industrial de Camaçari. Relatório Interno, 1, 2012.

COSTA W.D. Avaliação de Reservas, Potencialidades e Disponibilidades de Aquíferos. In: CONGRESSO BRASILEIRO DE ÁGUAS SUBTERRÂNEAS - ABAS, 10., 1998. [Anais...]. São Paulo, 1998.
CPRM. Serviço Geológico do Brasil. Mapa Geológico do Estado da Bahia: arquivo digital, 1990. Disponivel em: http://geobank.cprm.gov.br/. Acesso em: 03 maio 2016. Escala 1:1. 000.000. GEOBANK: gdba_lito.

CPRM. Serviço Geológico do Brasil. Hidrogeologia: conceitos e aplicações. Recife: UFPE / Laboratório de Hidrogeologia, 2000.

DE STEFANO L.; LOPEZ-GUNN, E. 2012. Unauthorized groundwater use: Institutional, social and ethical considerations. Water Policy, 14(S1), p. 147-160, 2012. https://doi.org/10.2166/wp.2012.101

FETTER C.W. Applied hydrogeology. Third Edition. University of Wisconsin - Oshkosh. Prentice Hall, 1994. 691 p.

GLEICK, P. Water in crisis: a guide to the world's fresh water resources. New York: Oxford University Press, 1993.

IBGE - EMBRAPA. Mapa de Solos do Brasil. Escala 1:5.000.000. Rio de Janeiro, 2001. Available in: http://www.dpi.inpe.br/Ambdata/mapa_solos.php.

INMET. Instituto Nacional de Meteorologia. Banco de dados meteorológicos para ensino e pesquisa: arquivo digital. Ministério da Agricultura, Pecuária e Abastecimento, 2017. Disponível em: http://www.inmet.gov.br/portal/index.php?r=bdmep/bdmep. Accessed in: 04 aug. 2017.

LALL U., HEIKKILA T.; BROWN C.; SIEGFRIED, T. Water: a global challenge: water in the 21st Century: Defining the Elements of Global Crises and Potential Solutions. Journal of International Affairs, v. 61, n. 2, p. 1-17, 2008.

LIMA O.A.L. Caracterização hidráulica e padrões de poluição no aquífero recôncavo na região de camaçari - Dias D'Ávila. Tese para Concurso Público de Professor Titular, Departamento de Geologia e Geofísica Aplicada, Instituto de Geociências, Universidade Federal da Bahia, 1999. 123 p.

MOENCH M.; KULKARNI H.; MACDONALD, D. The management challenge: what can be done? In Community management of groundwater resources in rural India. In: CALOW, R. ; MACDONALD, D. (eds.). British Geological Survey Commissioned Report $C R / 05 / 36 N$, p. 39-70, 2005.

MONTGINOUL, M.; RINAUDO J.D.; BROZOVIC, N.; DONOSO, G. Controlling groundwater exploitation through economics instruments: current practices, challenges and innovative approaches. In: Integrated Groundwater Management, Verlag: Springer International Publishing, 2016. https://doi.org/10.1007/978-3-319-23576-9 22

ROEDEL, R. M. Proposição de critérios técnicos para outorga de águas subterrâneas. Estudo de caso: polo industrial de Camaçari. 2017. Dissertação (Mestrado em Engenharia ambiental Urbana) - Departamento de Engenharia Ambiental, Universidade Federal da Bahia Salvador, 2017

SANTOS, P.R.P. Estudo da vulnerabilidade à poluição do aquífero marizal na região de influência do polo industrial de Camaçari (PIC) - BA. Dissertação (Mestrado Profissional em Gerenciamento e Tecnologias Ambientais no Processo Produtivo - MEPLIM) - Departamento de Engenharia Ambiental, Universidade Federal da Bahia, 2010. 
SCANLON, B.R.; HEALY, R.W.; COOK, P.G. Choosing appropriate techniques for quantifying groundwater recharge. Hydrogeology Journal, v. 10, p. 18-39, 2002. https://doi.org/10.1007/s10040-001-0176-2

SHIKLOMANOV, I. A.; RODDA, J.C. (Eds.) World water resources at the be-ginning of the 21st century. Cambridge, UK: UNESCO International Hydrology Series, 2003.

TERRELL B.; JOHNSON P.; SEGARRA, E. Ogallala aquifer depletion: economic impact on the Texas high plains. Water Policy v. 4, n. 1, p. 33-46, 2002. https://doi.org/10.1016/S13667017(02)00009-0

TUCCI, C.E.M. Gestão de recursos hídricos superficiais no polo industrial de Camaçari. RHAMA Consultoria Ambiental Ltda, 2009.
VILLAR, P.C. Aquíferos transfronteiriços: Governança das Águas e o Aquífero Guarani. Curitiba: Showroom Juruá: Av. Munhoz da Rocha, 143 - Juvevê, 8 de jun. de 2015.

WATERLOO BRASIL. Zoneamento dos recursos hídricos subterrâneos na Região do Polo Petroquímico de Camaçari/BA. Relatório Interno Camaçari: Cetrel, 2003.

WHO. Progress on drinking water and sanitation. Update. Geneva: WHO, 2014.

Zhou, Y., 2009. A critical review of groundwater budget myth, safe yield and sustainability. Journal of Hydrology, v. 370, p. 207-2013, 2009. 